\title{
Full mouth rehabilitation of a patient using monolithic zirconia and dental CAD/CAM system: a case report
}

\author{
Sang-Hoon Lee, Hyung-In Yoon, In-Sung Yeo, Jung-Suk Han, Sung-Hun Kim* \\ Department of Prosthodontics, School of Dentistry, Seoul National University, Seoul, Republic of Korea
}

An accurate implant placement with ideal location is significant for long-term success of the implant. An exact evaluation of nearby anatomic structures such as quality of residual bone, an inferior alveolar bone and a maxillary sinus is required. For a prostheticdriven treatment, planned surgery, precise prosthesis and communication with the patient are significant requisites especially for full-mouth rehabilitation. In this case, the patient with severe alveolar bone resorption had a CT guided surgery supported by CT data and the data from scanning diagnostic wax-up. Afterward, edentulous area was restored by full mouth implant-supported prosthesis by using monolithic zirconia and CAD/CAM technique. This paper reports the outcome of the procedure which was remarkable both esthetically and functionally. (J Dent Rehabil Appl Sci 2018;34(3):196-207)

Key words: full mouth rehabilitation; implant supported fixed restoration; monolithic zirconia; guided surgery; computer-aided design/computer-aided manufacturing (CAD/CAM)

\section{서론}

부분 혹은 완전 무치악 환자에 있어서 임플란트를 이 용한 치료방법은, 임플란트 고정성 보철수복, hybrid 고 정성 보철수복, 임플란트 유지 혹은 지지 피개의치 등이 있다. 특히, 임플란트 고성성 보철수복은 가철성에 비해 심리적인 안정감, 유지관리의 용이성, 적은 식편압입, 수 명 등의 측면에서 우수한 장점이 있지만, 전반적인 골과 연조직 소실이 큰 경우 임플란트 수술의 난이도도 증가 하며, 심미적인 결과 역시 얻기 힘들 수 있다. ${ }^{1}$

그러므로 임플란트의 장기적인 안정을 위해서는 이상 적인 위치와 각도로 임플란트를 식립하는 것이 중요하 며, 이를 위해서는 잔존골의 양과 하치조신경, 상악동 등 의 해부학적 구조에 대한 정확한 평가가 필요하다. ${ }^{2}$ 또 한, 무치악 부위를 임플란트로 수복할 경우, 단순히 뼈가

*Correspondence to: Sung-Hun Kim

Professor, Department of Prosthodontics, School of Dentistry, Seoul National University, 101, Daehak-ro, Jongno-gu, Seoul, 03080, Republic of Korea Tel: +82-2-2072-2661, Fax: +82-2-2072-3860, E-mail: ksh1250@snu.ac.kr Received: May 10, 2018/Last Revision: July 21, 2018/Accepted: August 6, 2018
있는 곳에 식립하는 개념(bone driven)에서 벗어나, 수 복 중심 치료(prosthetic driven)에 관심을 갖기 시작했으 며, 이를 위해서는 계획에 따른 정확한 수술과 보철, 그리 고 의사소통이 중요하다. ${ }^{3}$ 특히 전악 임플란트 수복에서 는 그 중요성이 더 커지며, 최근 $\mathrm{CAD} / \mathrm{CAM}$ 기술의 발전 으로 계획했던 위치에 보다 근접하게 임플란트를 식립한 후 계획한 최종 보철물을 제작할 수 있다. ${ }^{3}$

최종보철물의 수복재료로 여러 재료들이 고려될 수 있 는데, 현재 지르코니아를 이용한 보철수복의 빈도가 계 속 증가하는 추세이다. 지르코니아 수복물에서 심미 및 광학적 특성을 향상시키기 위해 많은 연구가 있어왔다. 지르코니아에 산화물을 첨가하여 각 층마다 색을 달리한 multi layered block이나, 투명성을 증가시킨 cubic phase zirconia 등이 현재 임상에서 많이 사용되고 있다. ${ }^{4,5}$

본 증례에서는 치주질환에 의해 치아를 상실한 후 완 
전 무치악 환자에게 CT guided surgical stent를 이용하 여 다수의 임플란트를 식립하고, 단일구조(monolithic) 수복용 지르코니아로 전악을 수복하였으며, 이에 심미적 및 기능적으로 좋은 결과를 얻어 이를 보고하고자 한다.

\section{증례보고}

\section{1. 진단 및 술 전 준비}

56세 남성이 잇몸이 안좋고 이가 많이 흔들린다는 주 소로 본원에 내원하였다(Fig. 1). 혈전용해제 복용 중이었 고 하루에 한 갑 이상 흡연을 하고 있었다. 기타 구강악 습관은 존재하지 않았다. 임상적, 방사선학적 검사에서 14 번 임플란트의 thread exposure 관찰되고, 구치부의 소 실로 인해 견치에서 flaring관찰되었다(Fig. 2). 전악 발치 가 필요한 사항이었으나, 환자는 최소한의 발치를 원하 여 동요도 2이상의 치아 발치 후 임시틀니과정을 거치며 지대치를 다시 평가하기로 하였다. 발치 후 임시의치를 제작하고 2개월 동안 조직 조정재(COE-SOFT, GC Co., Tokyo, Japan)를 이장하여 사용하였다(Fig. 3). 2개월간의 치유기간을 거친 뒤 진단모형분석을 위해 예비인상을 채
득하여 모형을 제작하였다. 진단모형 분석 시 모든 잔존 치의 발거 및 14 번 부위의 임플란트 제거 필요하여 모두 발거하기로 결정하였다. 환자는 가철성 보철물을 원하 지 않았으므로 상, 하악에 다수의 임플란트를 식립하여 고정성 보철물을 제작하기로 하였다. 환자의 수직고경 및 중심위를 채득하고 안궁이전하여 진단모형을 반조절 성 교합기(Hanau modular articulator system 190, Whip Mix Co., Louisville, USA)에 부착하였다. 진단납형을 통 해 치조골소실의 양이 많아 보철물 수복시 치은 및 치근 형태로의 수복이 예상되었다(Fig. 4).

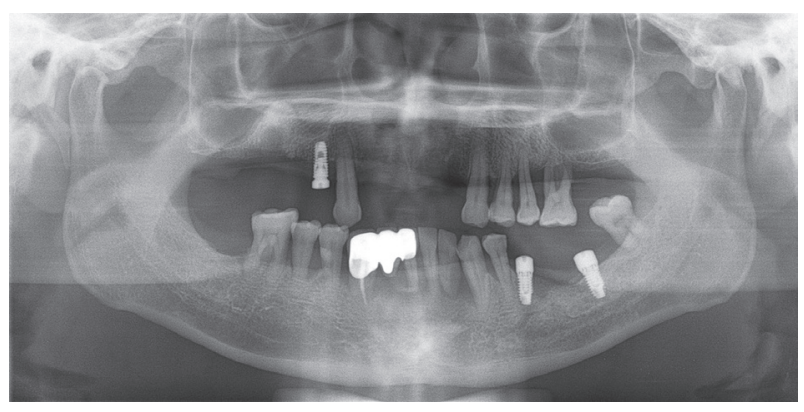

Fig. 1. Initial panoramic radiographic image. Generalized chronic periodontitis was shown.

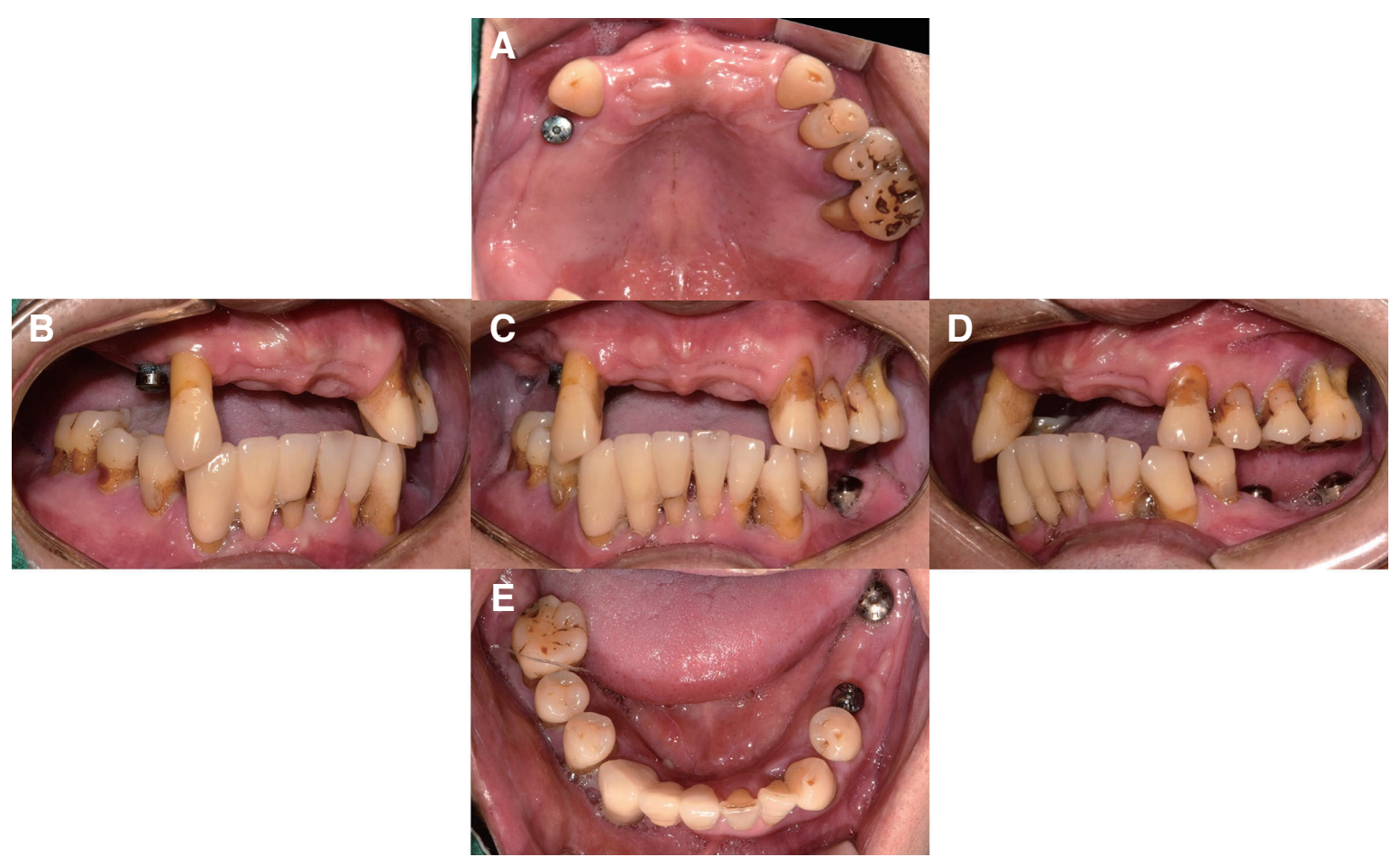

Fig. 2. Intraoral photograph in the initial examination. Generalized chronic periodontitis, implant fixture thread exposure, and irregular occlusal plane was shown. (A) Maxillary occlusal view, (B) Right lateral view, (C) Frontal view at maximum inter cuspal position, (D) Left lateral view, (E) Mandibular occlusal view. 


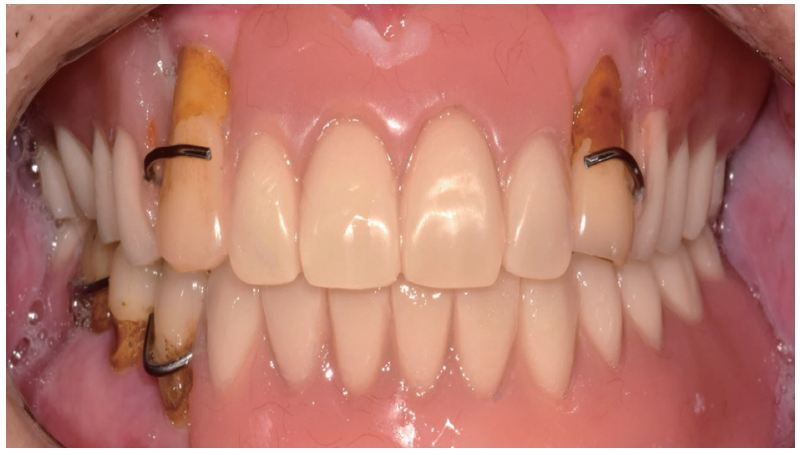

Fig. 3. Temporary denture delivery after teeth extraction.
Radiographic stent 착용 후 촬영한 CBCT와 진단모형 을 스캔한 자료를 중첩하여 원하는 위치에 임플란트 식 립을 계획하였다. CBCT 결과 \#17,27구치부 부위에 추 가적인 상악동 골이식을 계획하였다. 임플란트 진단 소 프트웨어(3Shape implant studio, 3Shape, Copenhagen, Denmark)를 이용하였으며 치료 계획에 따라 수술용 가 이드를 제작하였다. 수술용가이드는 식립에 따른 오차 및 드릴링으로 인한 열발생을 방지하기 위해, 드릴링의 홀은 open type으로 제작하여 추후 피판거상이 가능하 게 하였다(Fig. 5).
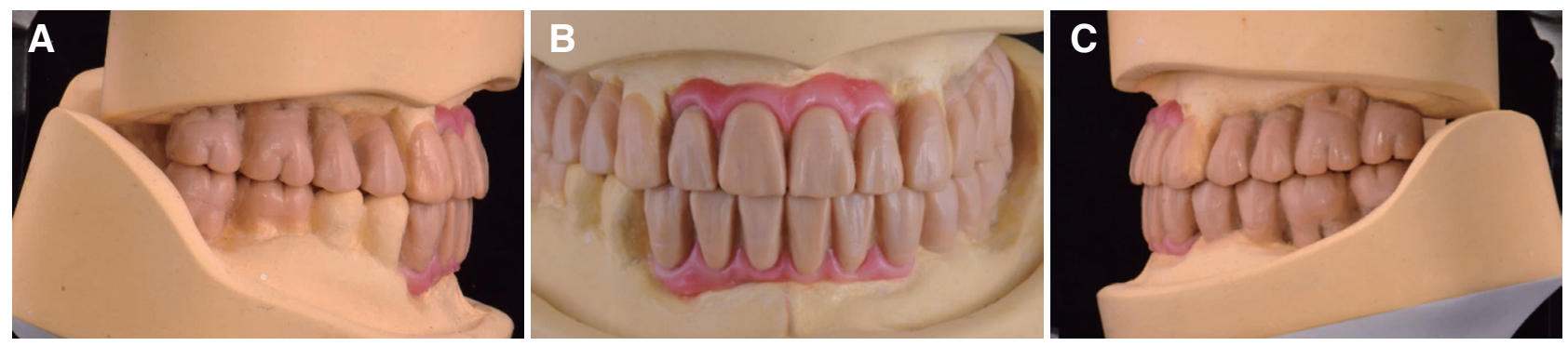

Fig. 4. Diagnostic wax-up model. (A) Right lateral view, (B) Frontal view, (C) Left lateral view.
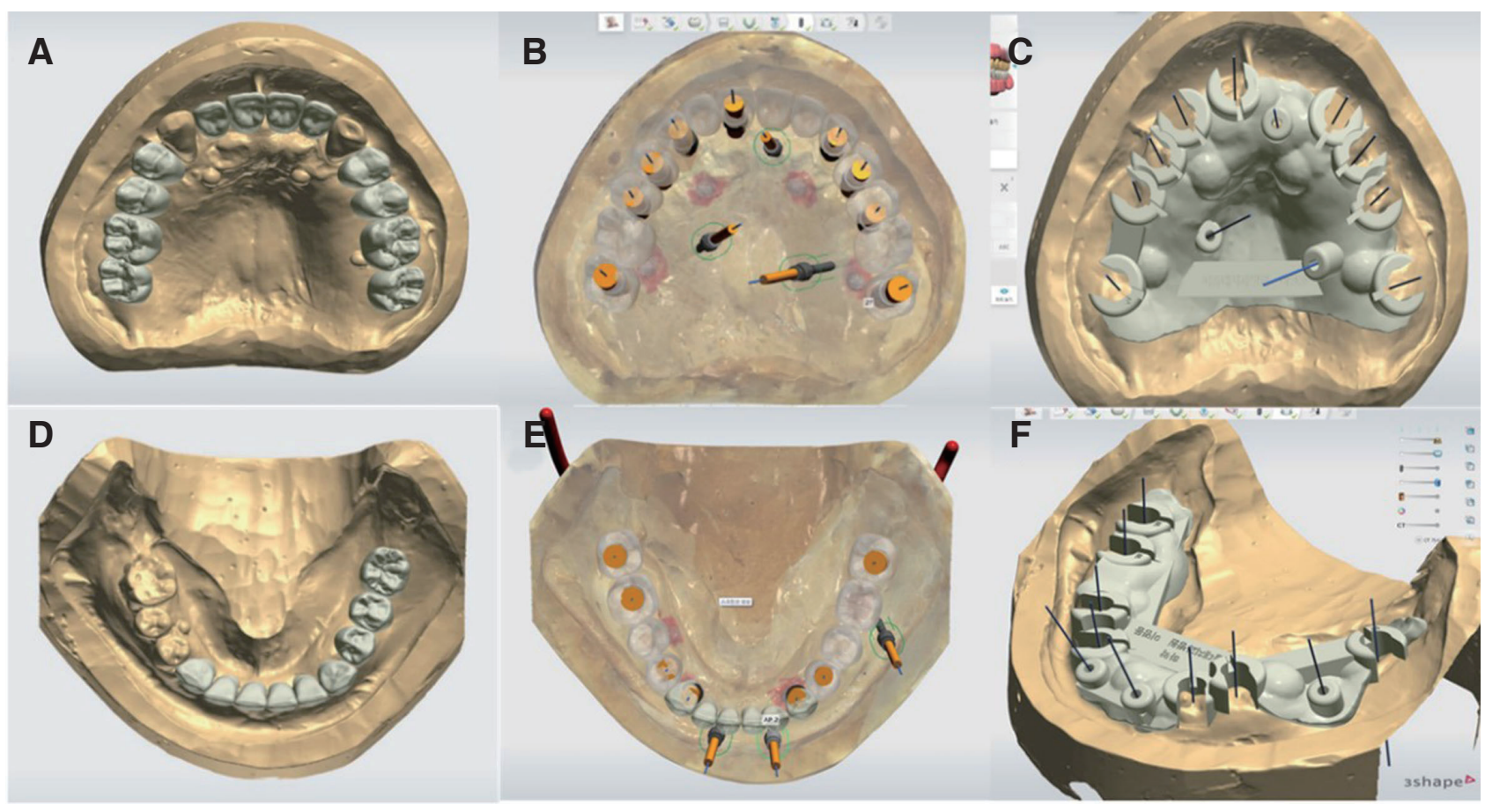

Fig. 5. Fabrication of surgical guide using CAD program. (A) Digital wax up of upper part, (B) Implant planning of upper part, (C) Surgical guide design of upper part, (D) Digital wax up of lower part, (E) Implant planning of lower part, (F) Surgical guide design of lower part. 

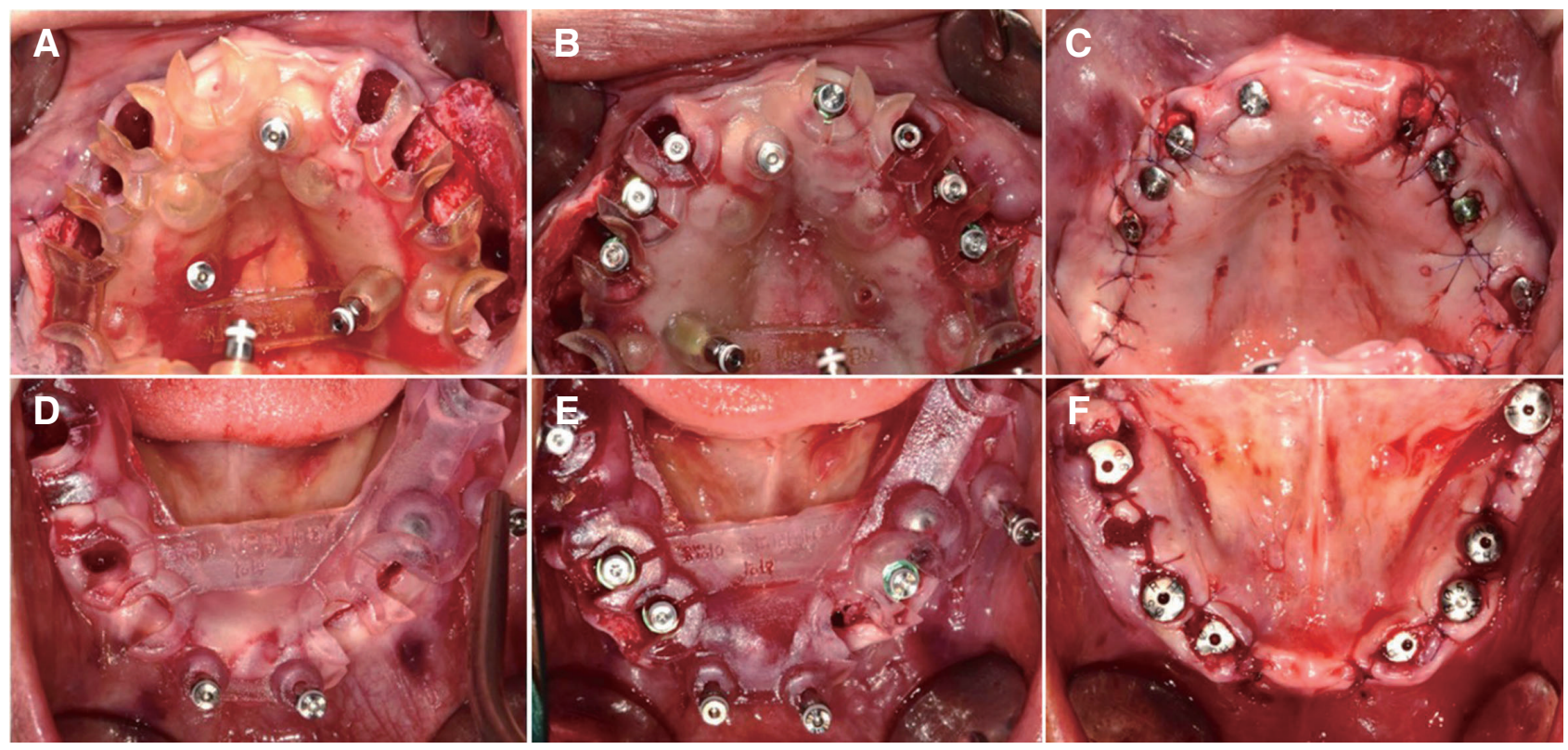

Fig. 6. Implant fixture placement. (A) Adaptation of maxillary surgical guide, (B) Maxilla after implant fixture placement, (C) Maxilla after surgery, (D) Adaptation of mandibular surgical guide, (E) Mandible after implant fixture placement, (F) Mandible after surgery.

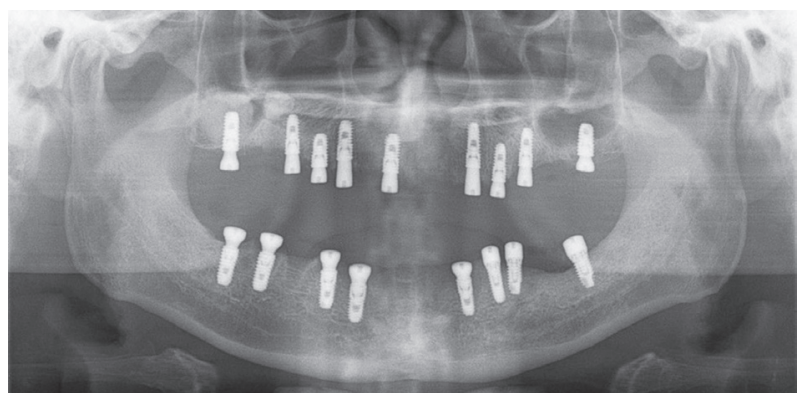

Fig. 7. Panoramic radiograph after implant fixture placement.

\section{2. 수술과정}

발치 3개월 후, 수술용 가이드를 이용하여 임플란트 식 립을 시행하였다. 수술용가이드는 3 개의 고정핀으로 고 정하였으며, \#13,14,15,17,21,23,24,25,27,33,43,44,46,47 의 위치에 14 개의 internal type의 임플란트(Osstem TS III, Osstem, Seoul, Korea)를 식립하였고, \#34 위치는 기존 식립된 external type의 임플란트과 동일한 종류의 임플란트(Osstem US III, Osstem, Seoul, Korea)를 식립 하였다. 모든 임플란트의 식립토크는 $35 \mathrm{Ncm}$ 이상으로 초기 안정성이 충분하였다(Fig. 6, 7).

\section{3. 임시보철물 제작}

7개월간의 임시의치 사용 후 임플란트 fixture 평가 시 특별한 병적 소견은 없었으며 임시수복물을 제작하기 로 하였다. Transfer impression coping을 이용해 예비 인상채득하고, 개인트레이를 제작 후, polyvinylsiloxane 인상재(Flexitime, Heraeus Kulzer GmbH, Hanau, Germany)와 Pick-up impression coping을 사용해 임시 보철물 제작을 위한 정밀인상채득을 시행하였다(Fig. 8). 교합제를 이용하여 1차 임시 보철물을 위한 수직고경 및 교합평면, 구순 지지 등을 결정한 다음 중심위를 채득하 였고, 안궁이전하여 반조절성 교합기에 마운팅하였다 (Fig. 9). Computer Aided Design (CAD)상에서 최종 보 철물 형태 왁스업 후 밀링하여 맞춤형 티타늄 지대주를 제작하였다. 임시수복물을 제작을 위해, PMMA block (YAMAHACHI Dental Products, Gamagori, Japan)을 milling하였다(Fig. 10,11). 맞춤형 지대주와 임시보철물 을 구강 내에 장착하고 약 2개월 동안 교합안정성 및 교 합고경, 구강위생 관리능력 등을 평가하였다(Fig. 12). 


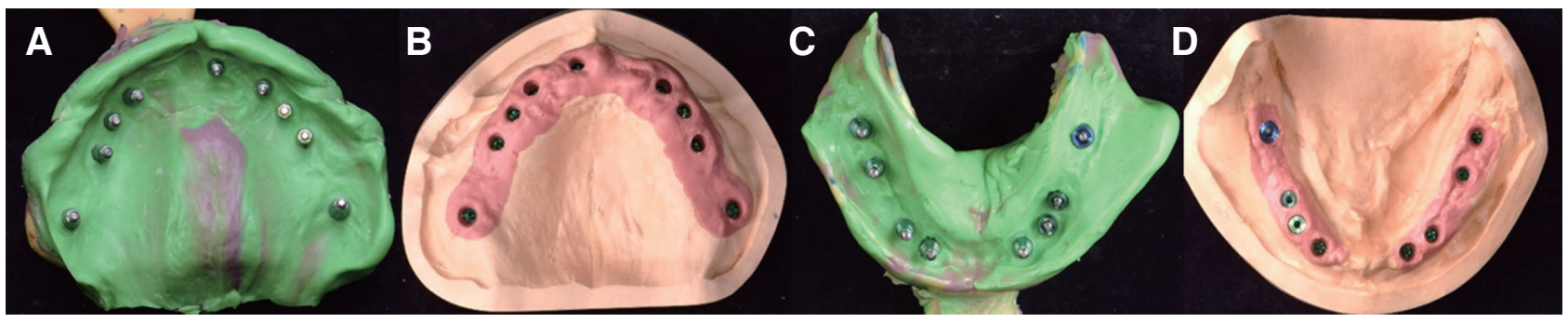

Fig. 8. Implant fixture level impression and master cast fabrication for provisional prosthesis. (A) Pick up coping impression of maxilla, (B) Master cast of maxilla, (C) Pick up coping impression of mandible, (D) Master cast of mandible.
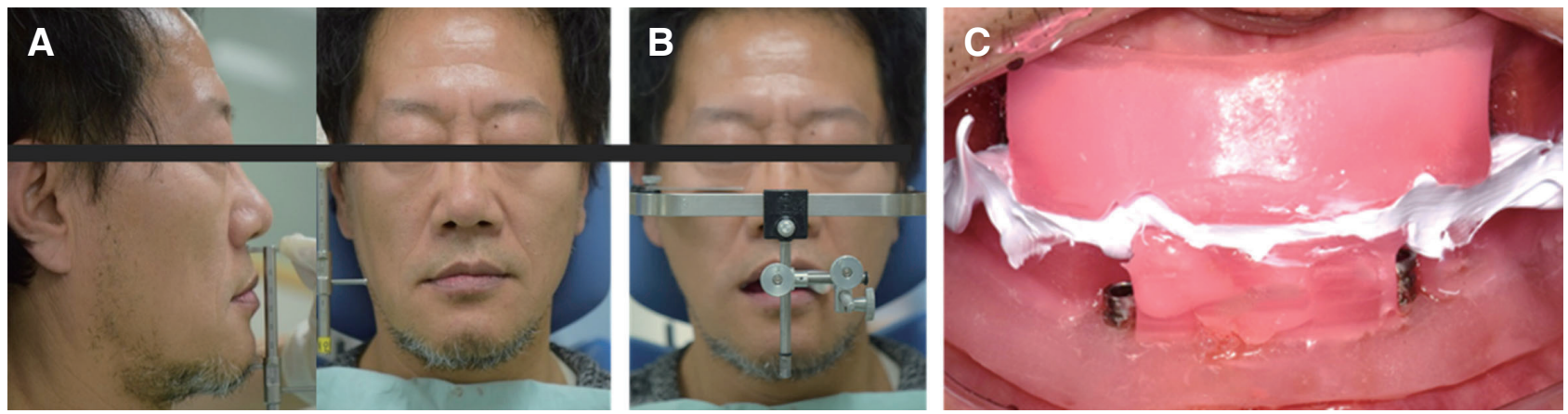

Fig. 9. Vertical dimension determination, facebow transfer, jaw relation registration for provisional prosthesis. (A) Vertical dimension at lateral view, (B) Vertical dimension at frontal view, (C) Facebow transfer, (D) Jaw relation registration.

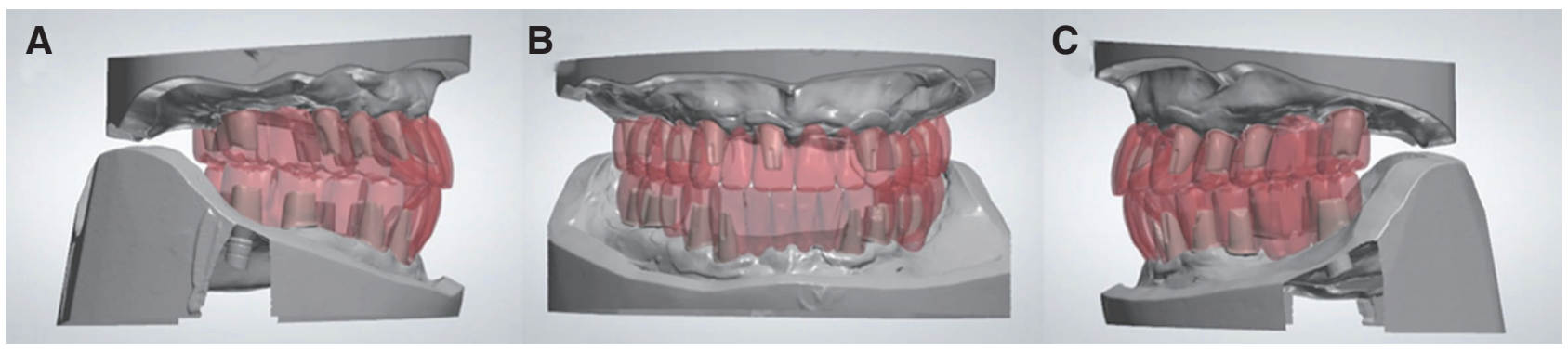

Fig. 10. Design of customized titanium abutment, digital wax up for provisional prosthesis. (A) Right lateral view, (B) Frontal view, (C) Left lateral view.

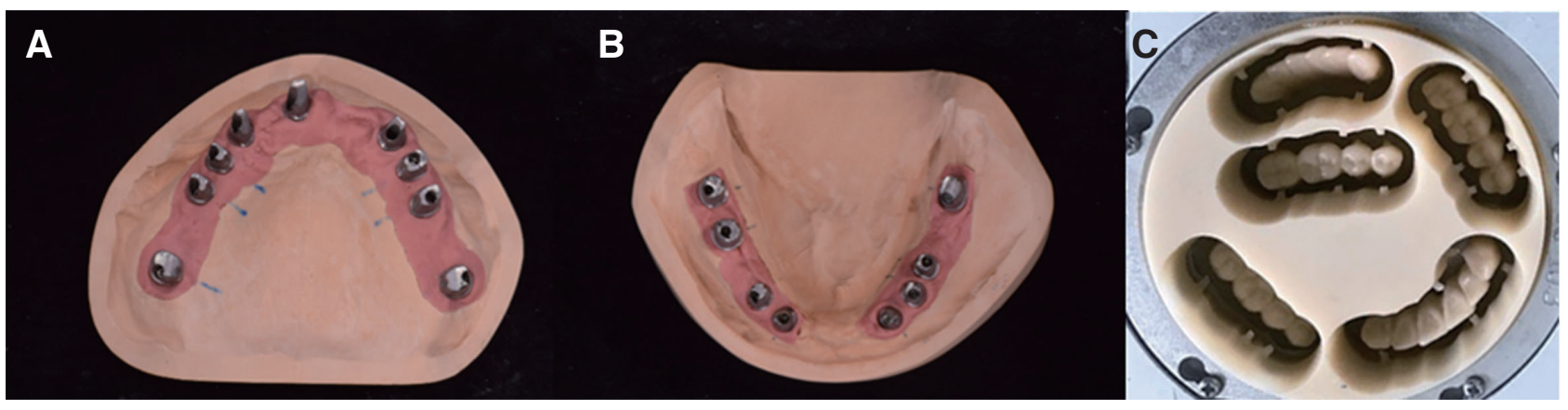

Fig. 11. Fabrication of customized abutment and provisional prosthesis. (A) Customized abutment of maxilla, (B) Customized abutment of mandible, (C) PMMA resin milling. 


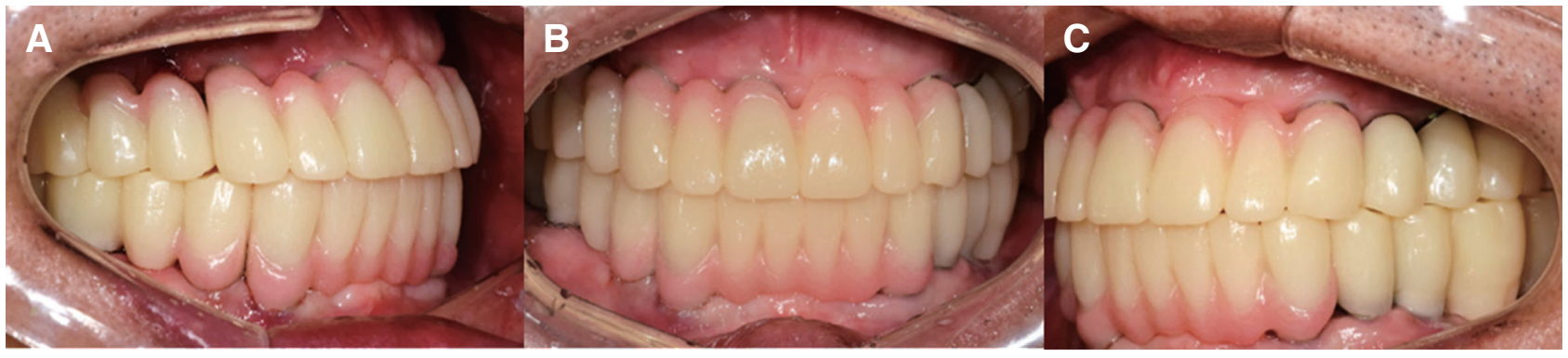

Fig. 12. Provisional prosthesis. (A) Right lateral view, (B) Frontal view, (C) Left lateral view.

\section{4. 최종보철물 제작}

2개월동안 임시수복물 사용 후 최종 인상 채득 전 30 $\mathrm{Ncm}$ 로 re-tightening 하였다. polyvinylsiloxane 인상재 (Flexitime, Heraeus Kulzer GmbH, Hanau, Germany) 를 이용해 지대주레벨에서 인상채득 후 작업모형제작 하였다(Fig. 13). 자가 중합형 아크릴릭 레진으로 제작 한 bite jig를 이용하여 임시 보철물이 장착된 상태의 수 직교합고경을 기준으로 한 최종 악간관계를 채득하였 다. 임시 보철물 장착 상태에서 비가역성 콜로이드 인상
재(Aromafine Plus, GC, Tokyo, Japan)로 인상 채득하 여 모형을 제작한 후 작업 모형과 cross mounting 하였 다(Fig. 14). 전치유도를 교합기에 기록하고, 체크바이트 법을 통해 과로 경사각도를 결정하였다. 주모형 스캔 후, 임시수복물 상에서 디자인된 치아배열을 참고하여 진행 하였다. 최종보철물로 이행하기 전, PMMA resin block (YAMAHACHI Dental Products, Gamagori, Japan)을 이용해 레진치를 2차로 밀링하였다. PMMA 레진을 밀링 한 임시수복물을, 구강내에 시적 후 안모 및 교합, 악간 관계를 평가하였다(Fig. 15). 다시 바이트 채득하여 마운

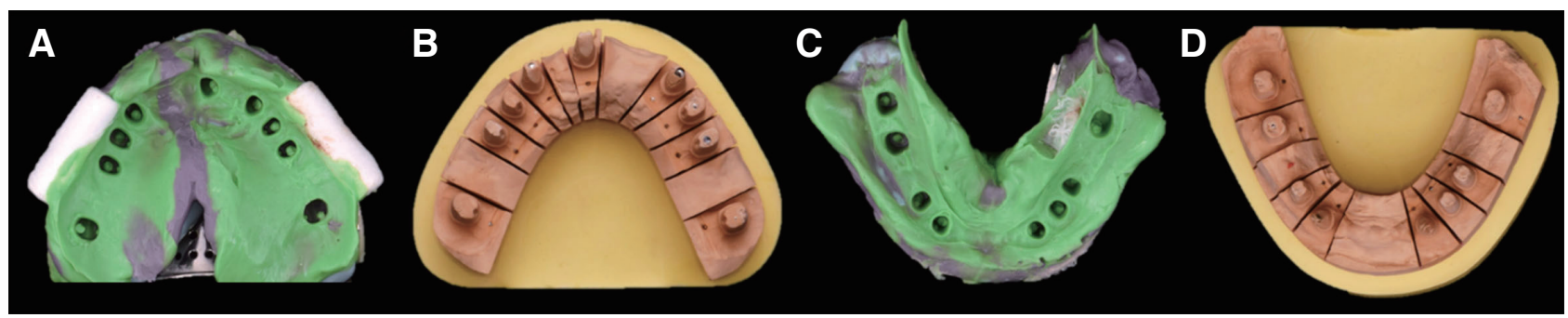

Fig. 13. Final impression and master cast fabrication for definitive prosthesis. (A) Final impression of maxilla, (B) Master cast of maxilla, (C)Final impression of mandible, (D) Master cast of mandible.
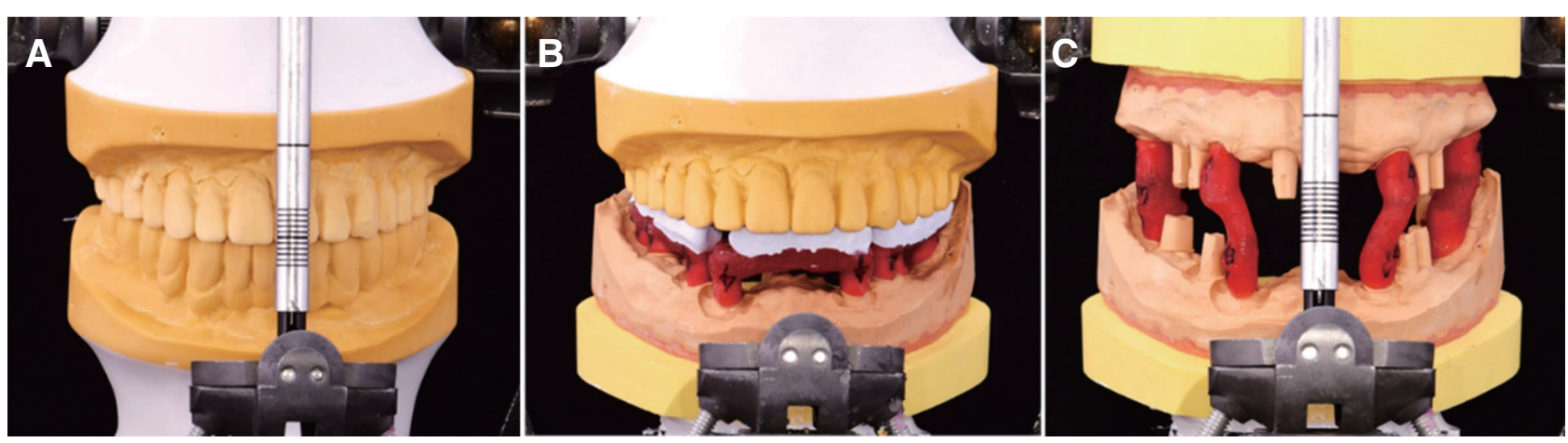

Fig. 14. Cross mounting. (A) Mounting of provisional restoration, (B) Mounting of mandibular master cast, (C) Mounting of maxillary Master cast. 


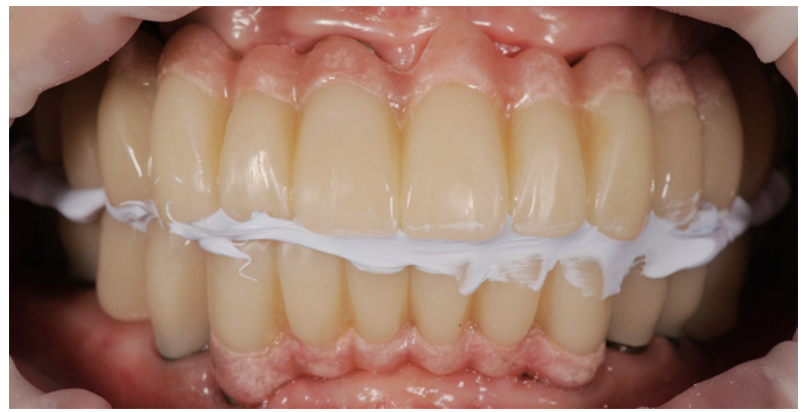

Fig. 15. Secondary provisional prosthesis. Facial profile, lip support, occlusion was re-evaluated.

팅 진행하였다.

전치부와 구치부에서 최종수복재료로 단일구조 수복 용 지르코니아블록을 사용하였다. 강도가 중요한 구치 부에는 굴곡강도 $1200 \mathrm{Mpa}$ 의 지르코니아 블락(Katana
Zirconia ML/HT, Kuraray Noritake Dental Inc., Tokyo, Japan)을, 투명감 및 심미성이 중요한 전치부는 굴 곡강도 $800 \mathrm{Mpa}$ 의 지르코니아 블락(Katana Zirconia STML, Kuraray Noritake Dental Inc., Japan)을 사용하 였다. 밀링 후 sintering하여 모델상에서 적합도를 확인한 후, Glazing전 다시 한번 구강내 시적 후 인접면 접촉과 교합을 확인하였다(Fig. 16, 17). T-scan을 통해 최대교합 시 구치부에서의 균등한 접촉이루어짐을 확인하였고, 측 방운동시 견치부터 제 2 소구치까지 군기능 교합을 부여 하였다. 보철물을 구강 내에 레진 시멘트 $\left(\right.$ Premier $^{\mathrm{TM}} \mathrm{Im}$ plant Cement ${ }^{\mathrm{TM}}$, Premier Co., Plymouth Meeting, USA) 로 최종 접착하였다(Fig. 18, 19). 최종 보철물 장착 후 1 일, 1 주, 1 개월, 3 개월, 6 개월에 환자의 구강위생관리 능 력을 확인하였으며, 특이한 소견은 관찰되지 않았다(Fig. 20).

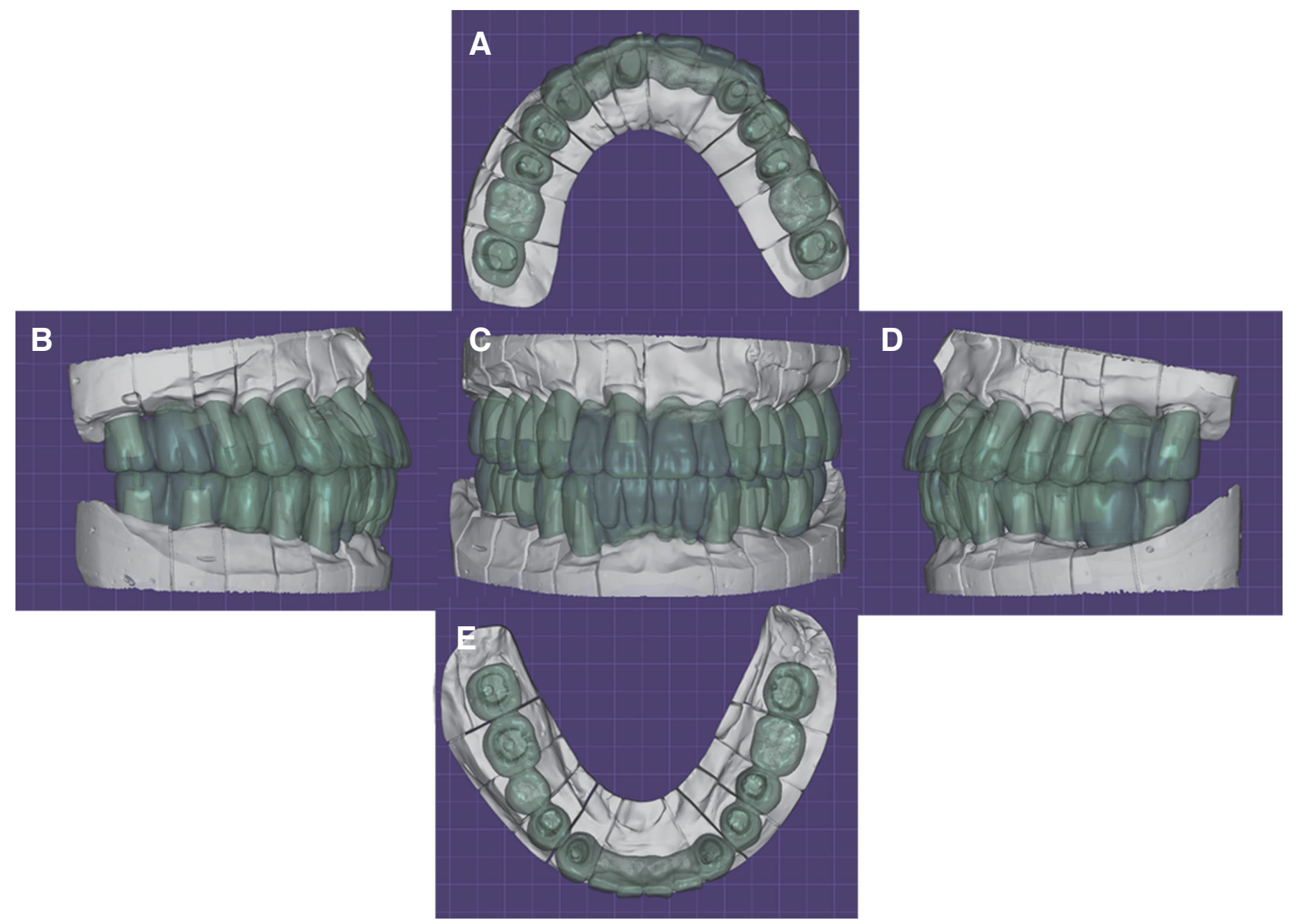

Fig. 16. Digital wax up of definitive prosthesis. (A) Maxillary occlusal view, (B) Right lateral view, (C) Frontal view, (D) Left lateral view, (E) Mandibular occlusal view. 


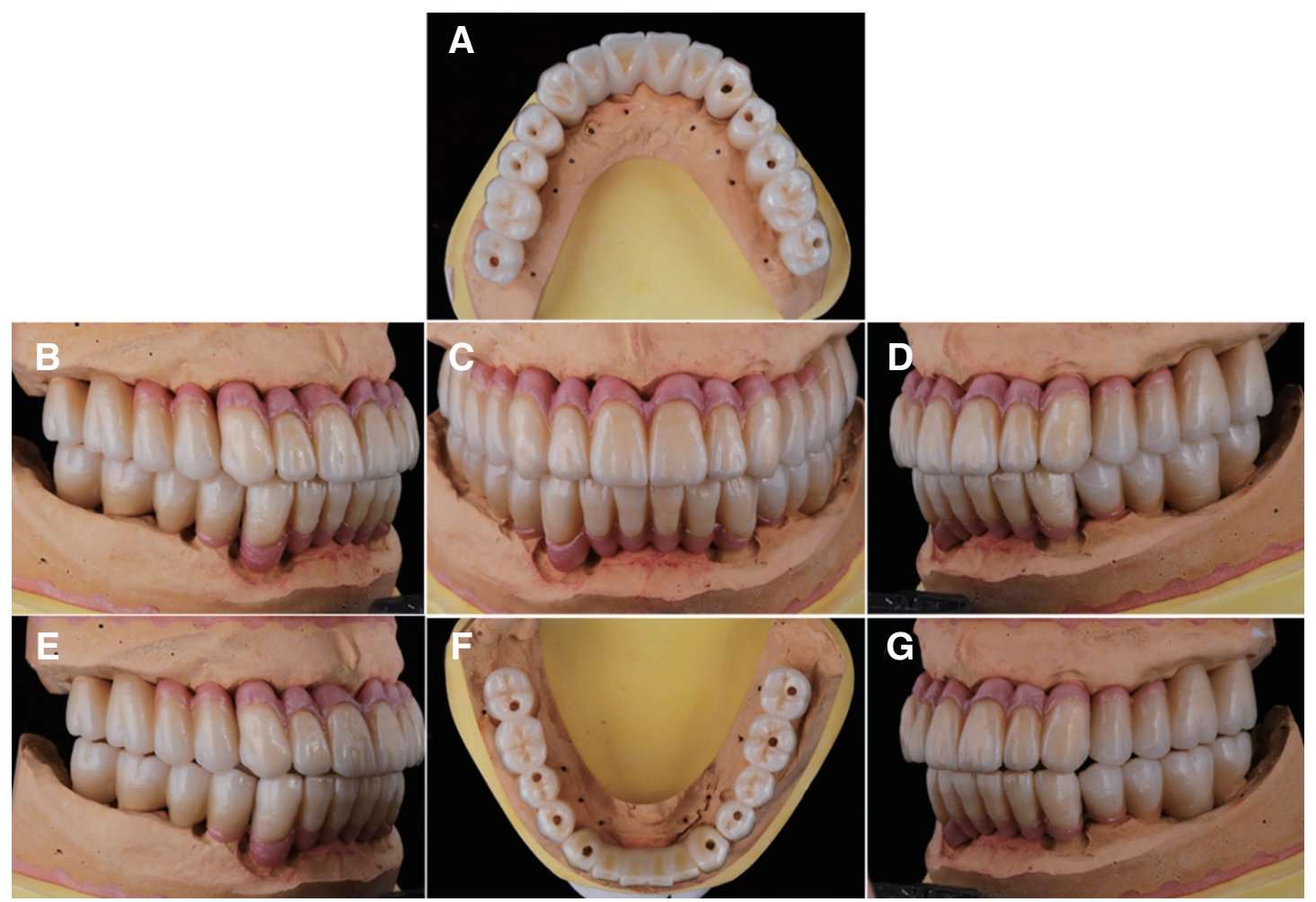

Fig. 17. Definitive prosthesis on master cast. (A) Maxillary occlusal view, (B) Right lateral view, (C) Frontal view, (D) Left lateral view, (E) Lateral movement - right side: group function, (F) Mandibular occlusal view, (G) Lateral movement - left side: group function.

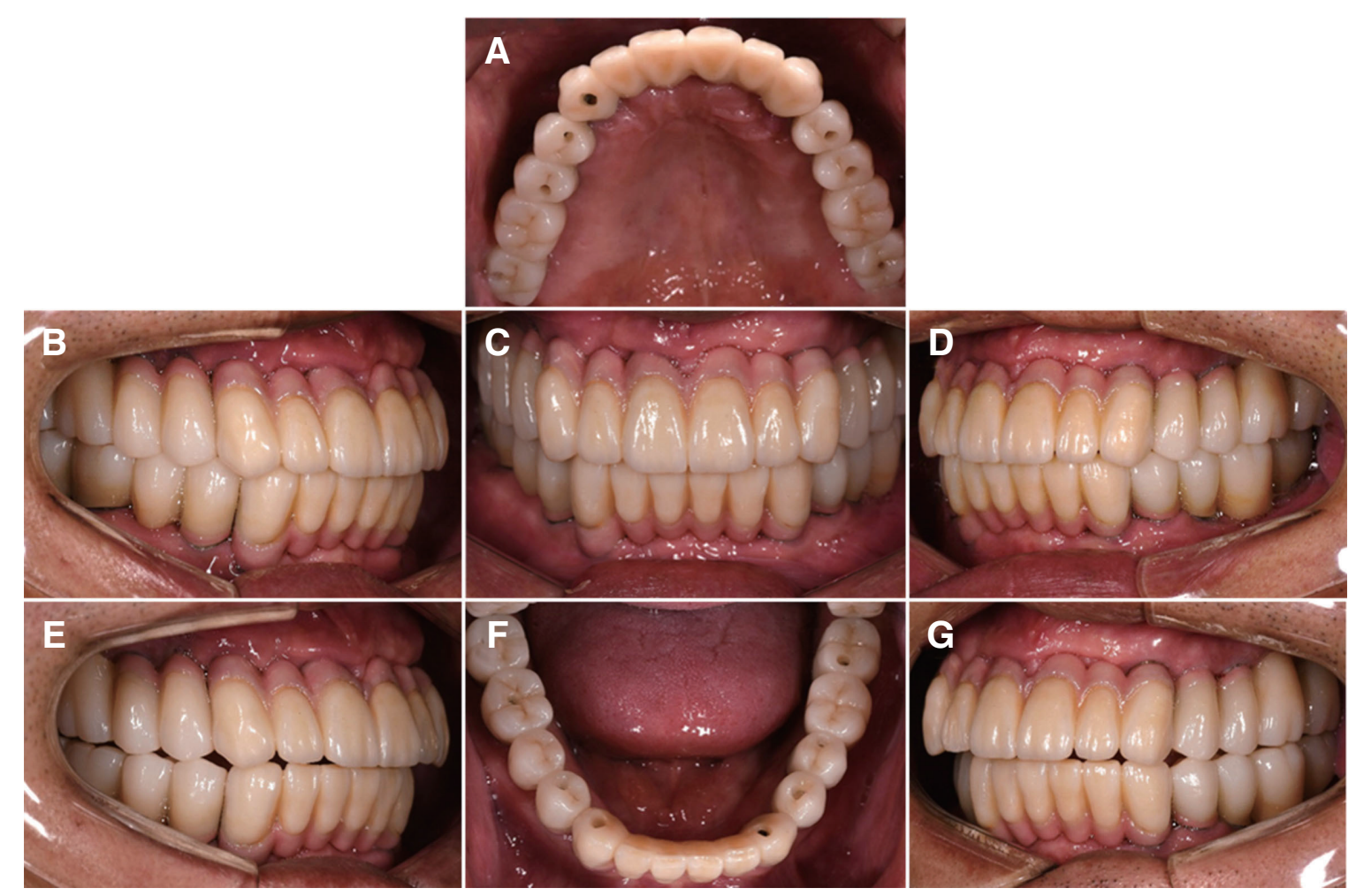

Fig. 18. Definitive prosthesis delivery. Group function with shallow anterior guidance was adopted for occlusal scheme. (A) Maxillary occlusal view, (B) Right lateral view, (C) Frontal view, (D) Left lateral view, (E) Lateral movement - right side: group function, (F) Mandibular occlusal view, (G) Lateral movement - left side: group function. 


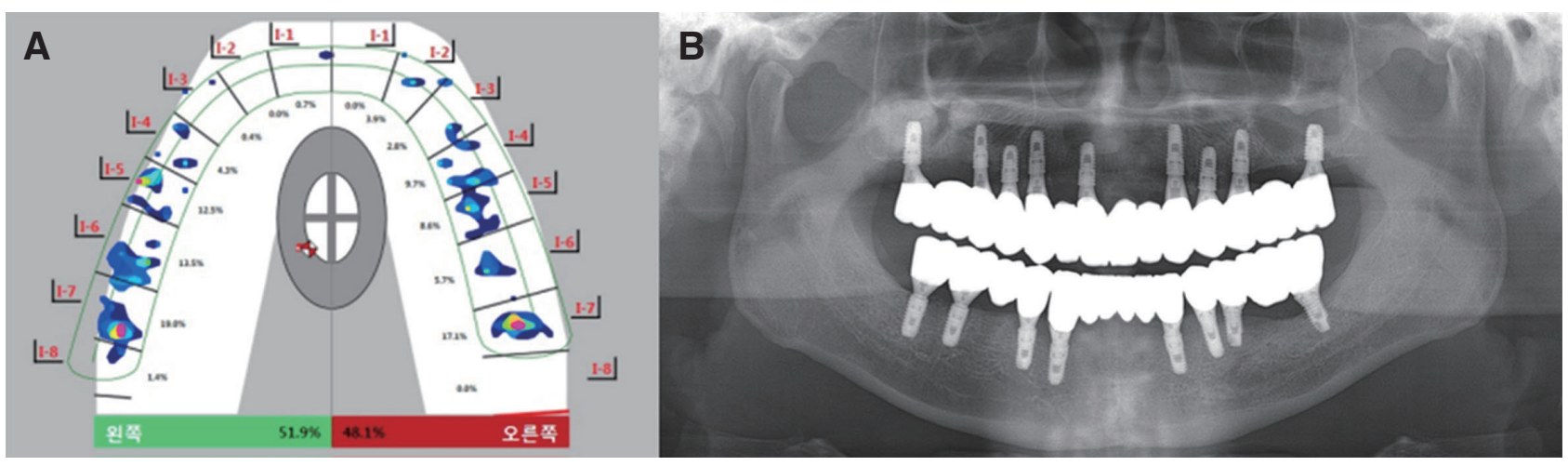

Fig. 19. Definitive prosthesis evaluation. (A) Occlusal analysis using T-scan III: Equal distribution of occlusal force for whole dentition, (B) Post-treatment panoramic radiograph.

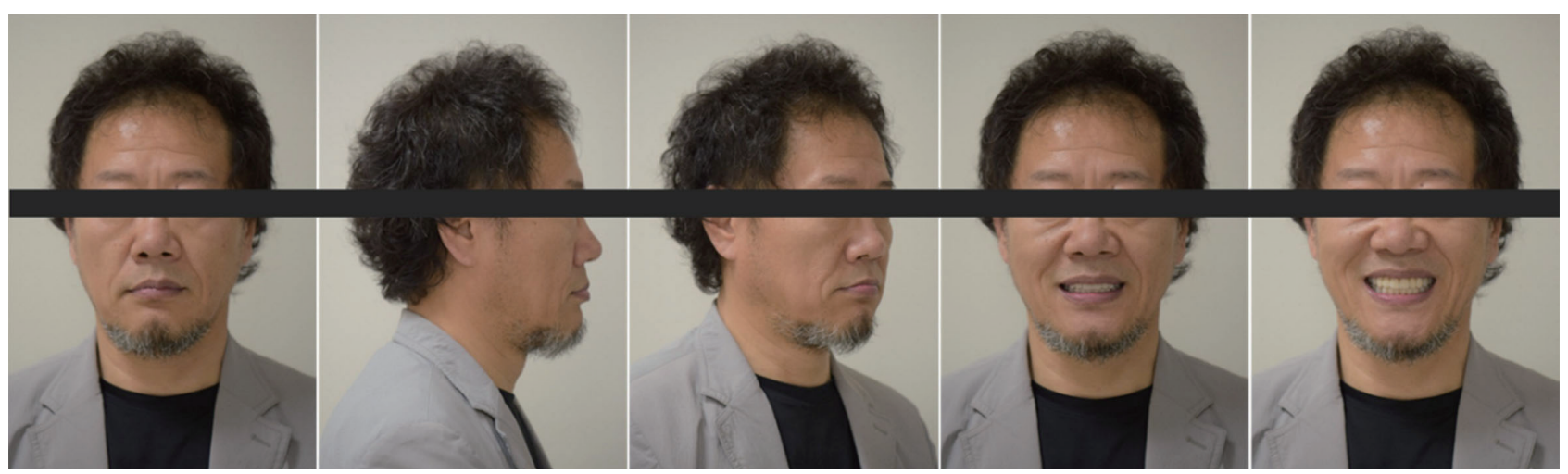

Fig. 20. Extraoral photograph after treatment. The treatment was remarkable both esthetically and functionally.

\section{고찰}

무치악환자에 있어서 임플란트를 이용한 치료를 계획 할 때, 임플란트 지지고정성 보철물 혹은 임플란트를 이 용한 가철성 보철물로 크게 나눌 수 있다. ${ }^{1}$ Zitsmann 등 이 제시한 무치악 환자의 임플란트 보철에서 고정성 또 는 가철성 수복시 고려할 사항을 살펴보면, 환자의 선호 도, 구역반사정도, 구강위생 관리상태, 경제적능력들을 평가해야 한다. 본 증례는 구순지지 및 안모지지 결손이 심하지 않았고, CT영상분석시 임플란트 식립을 위한 잔 존골이 충분하였다. 또한, 환자분께서 강력하게 고정성 보철수복을 원했기 때문에, CT guided surgery를 통한 임플란트 고정성 보철 치료를 하기로 결정하였다.

본 증례에서는 완전 무치악 환자의 임플란트 수술에 있어 mucosa supported surgical guide를 제작하여 임 플란트 식립수술을 진행하였다. Raico Gallardo 등 ${ }^{7}$ 은 supported tissue 간 오차를 측정하였으며 그 결과 tooth supported guide가 가장 높은 정확도를 보였고 mucosa supported guide, bone supported guide 순서로 낮은 정확도를 보였다. Bone supported guides는 많은 flap elevation이 요구되므로 reflected tissue에 의한 오차가 발 생할 수 있어 본 증례에서는 선택되지 않았으며 정확도를 높이기 위하여 3개의 fixation pin을 사용해 stent를 고정 한 mucosa supported guide를 선택하였다. Sun 등 ${ }^{8}$ 은 치 은 조직에 직접 접촉하는 template의 정확성을 측정하였 는데, 상악에는 평균 $1.8 \mathrm{~mm}$ 의 편차가 있었고, 하악에서 는 평균 $2.3 \mathrm{~mm}$ 의 편차를 보고하며, 임플란트 식립 시 최 소 $2 \mathrm{~mm}$ 의 safety margin을 두어야 한다고 주장하였다. 따라서 guide hole을 open type으로 만들어 수술 시 flap 을 거상하여 최종 식립 위치를 확인하였다.

완전 무치악 환자의 경우 본래의 교합이나 심미에 대 한 정보가 부족하므로 의사는 이를 재설정 해주어야 한 
다. 본 증례에서는 최종 보철물 제작 전 1,2 차 임시 보철 물을 제작하였는데, 먼저 교합 고경 및 평면, 구순 지지 등을 설정하여 맞춤형 지대주를 제작한 후 시멘트 유지 형 1차 임시 보철물을 제작하였다. 약 2 개월간 교합 안정 성 및 수직교합고경, 심미, 구강위생 관리능력 등을 평가 한 후 체크 바이트를 이용하여 환자의 과로각을 측정하 고 절치유도각을 설정하여 2차 임시 보철물을 제작하였 다. 2 차 임시보철물은 최종 보철물로 이행하기 전에 안모 및 교합평가를 위한 시적용으로 제작되었으며, 동일한 디자인 파일을 이용하여 최종 보철물 제작이 가능해, 최 종보철물 제작전 수정사항을 최종적으로 반영할 수 있는 장점이 있다.

Kim 등 ${ }^{9}$ 은 생역학적인 요소를 고려한 임플란트 교합 의 가이드라인을 제시하였는데, 전악 임플란트 고정성 보철물인 경우 군기능 또는 상호보호 교합을 부여해야 한다고 하였다. 교합 과하중은 임플란트 실패의 원인이 될 수 있으며, 자연치와는 다르게 임플란트는 치주인대 가 없어 더 큰 하중을 발생시킬 수 있다. 따라서 이번 증 례에서는 견치부터 제 2 소구치까지 군기능교합을 부여하 여, 교합분산을 얻을 수 있도록 노력하였다.

최종보철물의 재료로는 지르코니아가 사용되었는데, 지르코니아는 강도와 심미성이 우수한 재료로 현재 다양 한 보철치료에 사용되고 있다. ${ }^{10}$ 그러나 지르코니아-도재 보철물 수복시 약한 결합강도로 인해 상부도재 파절의 문제점이 빈번하게 발생하였고, ${ }^{11}$ 지르코니아 코어에서 도 파절이 발생하여 큰 문제점으로 지적되었다. ${ }^{12}$ 하지만, Badissara 등 ${ }^{5}$ 은 단일구조 수복용 지르코니아의 투명도 와 색조가 개선되어 전치부에서도 도재축성없이 적용이 가능하다는 연구 결과를 발표하였다. 따라서 본 증례에 서는 cubic phase가 첨가되어, 투명성이 증가되고, 각 층 마다 산화물을 첨가하여 색을 달리한 단일구조 수복용 지르코니아를 이용하여 전악수복하였다. 전치부에서는 굴곡강도 $800 \mathrm{MPa}$ 의 지르코니아 블록을 사용하여 심미 및 투명성을 증가시켰고, 구치부에서는 굴곡강도 1200 $\mathrm{MPa}$ 의 지르코니아 블록을 사용하여 교합력에 대해서 저항할 수 있는 기계적 강도를 증가시켰다. Bidra 등 ${ }^{13}$ 은 systematic review를 통해 단일구조 지르코니아 보철물 이 짧은 기간에서는 매우 낮은 보철적 합병증을 보인다 고 보고하였다. 하지만 전악을 임플란트 지지 단일구조 지르코니아로 수복한 보철물에 대한 장기적인 연구는 미 비하기 때문에, 재료선택에 있어서 조심스러운 접근이 필 요하다.

\section{결론}

본 증례는 치주질환에 의해 치아를 상실한 완전 무치 악 환자에게 CT data 및 진단왁스업을 scan한 data를 이 용하여 제작한surgical stent로 계획된 위치에 임플란트 를 식립하고, $\mathrm{CAD} / \mathrm{CAM}$ technique를 통해 단일구조 (monolithic) 수복용 지르코니아로 전악을 수복하였다. 이를 통하여 만족할만한 심미 및 기능적인 결과를 보였 기에 본 증례를 보고하는 바이다.

\section{ORCID}

Sang-Hoon Lee https://orcid.org/0000-0003-2209-4813 Hyung-In Yoon https://orcid.org/0000-0002-9597-6342 In-Sung Yeo https://orcid.org/0000-0002-6780-2601

Jung-Suk Han https://orcid.org/0000-0002-9439-1465

Sung-Hun Kim https://orcid.org/0000-0003-3289-9703

\section{References}

1. Misch CE. Dental implant prosthetics. 2nd ed. St. Louis; Mosby; 2015. p. 193-205.

2. BouSerhal C, Jacobs R, Quirynen M, van Steenberghe D. Imaging technique selection for the preoperative planning of oral implants: a review of the literature. Clin Implant Dent Relat Res 2002;4:15672.

3. Harris BT, Chen L, Lin WS. Digital Imaging and Prosthetic-Driven Implant Planning: Efficient, Accurate, and Reliable Treatment. Compend Contin Educ Dent 2017;38:492-4.

4. Ueda K, Güth JF, Erdelt K, Stimmelmayr M, Kappert $\mathrm{H}$, Beuer F. Light transmittance by a multi-coloured zirconia material. Dent Mater J 2015;34:3104.

5. Baldissara P, Wandscher VF, Marchionatti AME, Parisi C, Monaco C, Ciocca L. Translucency of IPS e.max and cubic zirconia monolithic crowns. J Prosthet Dent 2018;120:269-75.

6. Zitzmann NU, Marinello CP. Treatment plan for restoring the edentulous maxilla with implantsupported restoration: removable overdenture versus fixed partial denture design. J Prosthet Dent 1999;82:188-96. 
7. Raico Gallardo YN, da Silva-Olivio IRT, Mukai E, Morimoto S, Sesma N, Cordaro L. Accuracy comparison of guided surgery for dental implants according to the tissue of support: a systematic review and meta-analysis. Clin Oral Implants Res 2017;28:602-12.

8. Sun Y, Luebbers HT, Agbaje JO, Schepers S, Politis C, Van Slycke S, Vrielinck L. Accuracy of Dental Implant Placement Using CBCT-Derived MucosaSupported Stereolithographic Template. Clin Implant Dent Relat Res 2015;17:862-70.

9. Kim Y, Oh TJ, Misch CE, Wang HL. Occlusal considerations in implant therapy: clinical guidelines with biomechanical rationale. Clin Oral Implants Res 2005;16:26-35.

10. Stawarczyk B, Keul C, Eichberger M, Figge D, Edelhoff D, Lümkemann N. Quintessence Int 2017;48:441-50.
11. Wong CKK, Narvekar U, Petridis H. Prosthodontic Complications of Metal-Ceramic and All-Ceramic, Complete-Arch Fixed Implant Prostheses with Minimum 5 Years Mean Follow-Up Period. A Systematic Review and Meta-Analysis. J Prosthodont 2018 Apr 17. doi: 10.1111/jopr.12797. [Epub ahead of print]

12. Moráguez OD, Wiskott HW, Scherrer SS. Three- to nine-year survival estimates and fracture mechanisms of zirconia- and alumina-based restorations using standardized criteria to distinguish the severity of ceramic fractures. Clin Oral Investig 2015;19: 2295-307.

13. Bidra AS, Rungruanganunt P, Gauthier M. Clinical outcomes of full arch fixed implant-supported zirconia prostheses: a systematic review. Eur J Oral Implantol 2017;10:35-45. 


\section{단일구조 수복용 지르코니아와 Dental CAD/CAM System을 이용한 전악 임플 란트 고정성 보철 수복 증례}

\section{이상훈, 윤형인, 여인성, 한중석, 김성훈*}

서울대학교 치의학대학원 치과보철학교실

임플란트의 장기적인 안정을 위해서는 이상적인 위치와 각도로 임플란트를 식립하는 것이 중요하며, 이를 위해서는 정 확한 계획에 따른 정확한 수술과 보철이 중요하다. 본 증례에서는 치조골 흡수가 심하게 진행된 환자에서 CT data 및 진 단왁스업을 스캔한 data를 이용하여 CT guided surgery를 시행하고, 단일구조 수복용 지르코니아와 CAD/CAM technique을 이용하여 전악 임플란트 고정성 보철로 수복하여 기능 및 심미적으로 만족할만한 결과를 얻었기에 이를 보고하 고자 한다.

(구강회복응용과학지 2018;34(3):196-207)

주요어: 전악구강회복; 임플란트지지 고정성 보철물; 단일구조수복용 지르코니아; guided surgery; computer-aided design/ computer-aided manufacturing (CAD/CAM) 